\title{
MULTIMODAL METAPHOR AS THE SOURCE OF PARODIC INTEGRATION IN HIP HOP MUSIC VIDEOS
}

Original scientific paper Submitted: 3. 1. 2020. Accepted: 20. 10. 2020. DOI: $10.15176 / \mathrm{vol} 57 \mathrm{no} 204$ UDK 7.038.53:78

\section{GORDANA ČUPKOVIĆ}

Department of Croatian Studies, University of Zadar

\section{SILVANA DUNAT}

Arts Academy of the University of Split

\begin{abstract}
This paper deals with multimodal metaphors as the basis of parodic integration in selected videos and album covers by rap artist Krešo Bengalka and his band Kiša metaka. The case studies of parodic integration are marked by a spectacle that significantly contributes to the blend. The study focuses on multimodal integration and disintegration and on the reversal of the conventional way of representing both the relation between the interior and exterior and the relation between the static and the dynamic.
\end{abstract}

Keywords: cognitive semantics, conceptual metaphor, multimodal metaphor, spectacle, parody, gangsta rap

\section{INTRODUCTION}

Multimodal metaphors significantly complicate the two-dimensional mapping scheme (from source to target domain) primarily by going beyond the simplicity of a monosensory or even bisensory frame; the simultaneity of perceptual stimuli (auditory, visual and tactile stimuli can contain both linguistic and non-linguistic information) accompanied by the activation of (linguistic and/or non-linguistic) knowledge in the mental space creates a particularly complex network of connotations also triggering new denotations. 'It is particularly interesting to observe how multimodal perceptual stimuli are used to generate parody and conceptual integration in music videos belonging to the genre that is predominantly provocative, but whose provocation oscillates between expressing social criticism and fit-

\footnotetext{
${ }^{1}$ Cf. Forceville (2016) for a description and classification of pictorial and multimodal metaphors.
} 
ting into genre clichés. It is actually the exploitation of clichés that brings forth conventional metaphor not only at the level of verbal expression but also in visual and auditory imagery.

The selected gangsta and trap pictorial and multimodal works (album covers and music videos) use parodic contrasting and reverse conventional representation, on verbal, visual and auditory levels, in order to give a commentary on both the life of an individual and the social group to which the individual belongs - the group can and does metonymically stand for a larger community such as a city and a state. ${ }^{2}$

In the work selected for analysis in this paper, the formalism of the genre is imbued with a spectacle, which is manifested by verbal and visual provocation, and stands in contrast to the intended social criticism. ${ }^{3}$ The reversal of social values generates the reversal between the high and the low; the parodic text is equated with a hypertext when it comes to its value markedness as well as its verbal and visual presentation.

\section{CONCEPTUAL INTEGRATION AND PARODY}

Parody in the broader sense of a word, as a juxtaposition of the signification of two entities and the transformation of that signification, demonstrates common traits with both metaphor and metonymy: it is based on establishing analogy and disanalogy between mental spaces (according to the theory of conceptual integration by Fauconnier and Turner 1998).

These mental spaces establish the object(s) of parody and parody itself. While metaphor and metonymy activate the conceptually-based connectors between different entities, parody exploits our knowledge and experience to establish the distinction between two comparable entities based on the dynamic nature of analogy. When it comes to parody, the similarity is actually antonymic: the comparison between similar entities emphasizes the elements of contrast that typically create a critical detachment. The object of parody can be style, convention, genre or discourse (cf. Korkut 2005) and parody does not have to affect only the verbal message (hypertextuality). On the contrary, the parodic relationship can be produced by visual signs alone (linguistic and non-linguistic) or by layering different

\footnotetext{
2 The genre of gangsta rap is characterized by a "harder" rap style and referentiality to crime, typically incorporating hypermasculinity, hyperviolence, and hypersexuality (cf. McCann 2017). Krešo Bengalka himself uses the notion of "hardness" to refer to his uncompromising approach to music and verses, saying that he actually combines rap and punk (cf. Jerković 2017).

${ }^{3}$ Gangsta topics providing social criticism are used in a specific way to "embellish" the content of a considerably less popular political rap. On the topic of the audience's preference for gansta rap over political rap, see Caldwell (2008). As a solo performer, Krešo Kulašin does not declare himself to be a gangsta rapper. In his more recent work, he uses a more diverse music style that takes him further away from gangsta rap. $\mathrm{He}$ is already recognized for his specific humor and cynicism in his work, and not only for his brutality and criticism (cf. Jerković 2017). In an interview, he compares his work as a solo artist with his work in the gangsta band Kiša metaka and says: "While Krešo Bengalka the solo artist, speaks out his mind, has no hidden agendas and does not shun his real personality, Krešo Bengalka in Kiša metaka was more of a parody of that guy" (Bukna 2018).
} 
modules of communication (hypermediality). In these cases, parody can be triggered by an intentional conflict between different modes: the verbal text and the image, the image, the sound and the verbal text, etc. Classical theories define parody as a contrast between the high and the low, that is, as the process of debasing or transposing a particular style to the topics of lower value (cf. Korkut 2005: 6). Parody achieves artistic value by contrasting the high and the low, but the contrast can also be realized within a single domain, either high or low; the parody and the object of its reference do not have to be value-marked in that sense. The features of simultaneity, intertextuality and intermediality bring parody into the very center of postmodern and posthumanist artistic expression (cf. Korkut 2005: 65).

Simultaneity characterizes both multimodal or multisensory integration and the integration of spatial (interior and exterior) and temporal (static and dynamic) contrasts. To put it simply, on a monomodal level, parodic relationships are based on an emphasized disanalogy between the properties of the input spaces producing a meaningful contrast and even a certain inconsistency in the integrated space: a property that is peripheral (or specific) in the generic space becomes the basis of the disanalogy and generates parodic integration. The same principle underlines the examples of conceptual integration which are based on the diversion from the standard conceptions of time and space. The premise of the paper is that the generic space includes not only semantic features but also conceptual metaphors and metonymies (which is in line with the understanding of polysemy in lexical relations, cf. Langacker 1987). Fauconnier and Turner (1998) also show a similar pattern in their discussion of causal metaphors.

Figure 1 represents the basic monomodal schema of parody and integration reversal, based on Fauconnier and Turner's conceptual integration schema (1998).

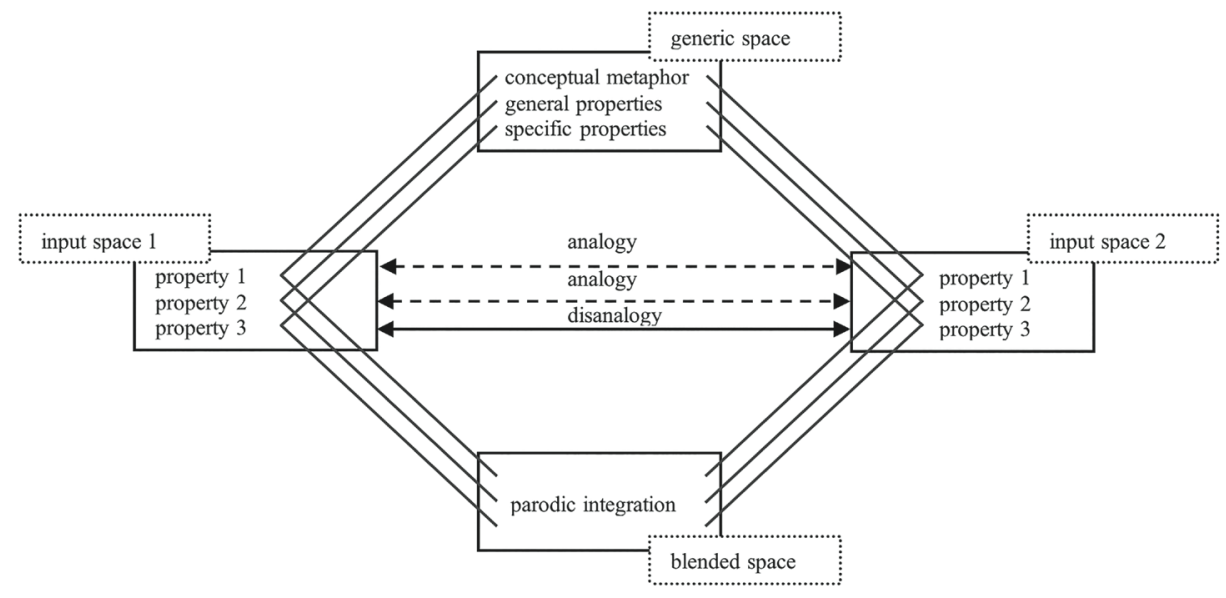


The investigated case studies provide cues for establishing a correlation between conceptual integration and parodic amalgamation as generators of new meaning. Both processes operate with different domains of meaning that are best characterized as mental spaces, ${ }^{4}$ since they incorporate both semantic anchoring in what could be best explained as common and fixed linguistic and cultural core knowledge on the one hand, and semantic creativity on the other. Conceptual integration can be triggered by metaphoric mapping, but this is not the condition sine qua non as it may also result from other kinds of established analogy and disanalogy between mental spaces.

On the one hand, parodic distancing from both the conventions of the genre and the reality represented in the videos is manifested in the disanalogous combination of the verbal message and the auditory and visual stimuli, while on the other hand, the disanalogy between the interior and the exterior space and between the static and the dynamic is revoked in order to achieve a critical, distorted and parodic representation of space and time. These forms of parodic integration are contextualized in terms of specific metaphoric phrases and leitmotifs and the underlying generic properties are identified at the conceptual level.

The aim of this paper is not to argue that parodic connections of domains such as reversals, inversions, transgressions or transmutations can be successfully explained solely by the processes of metaphorical and metonymical mappings or conceptual blending. Instead, we would like to show that parody, revealed in a multimodal context, exhibits semantic processes akin to those discussed in cognitive linguistics, which means that perhaps further investigation of parody can even produce significant new insights into conceptual metaphor and blending theory.

\section{CASE STUDIES}

\subsection{THE STATE AS A CRACK HOUSE}

The parody in the music video "Konan" by Kiša metaka incorporates various levels of communication modes: pictorial, verbal and auditory. An authentic documentary video clip (a filming of a 1995 military parade) is transferred from the conceptual domain of documentary films of historical events to the domain of gangsta rap, and this transfer is achieved through a simultaneous projection of image, music and verbal text. The military parade and the soundtrack of the Croatian anthem marked by a grand sound ${ }^{5}$ are in disa-

\footnotetext{
${ }^{4}$ Mental spaces are defined by Fauconnier and Turner (1998: 137) as "small conceptual packages constructed as we think and talk, for purposes of local understanding and action". In the process of communication, mental spaces, referred to as input spaces by Fauconnier and Turner, can be brought together and related in a common generic space, and based on their elements or structures of similarity they can be projected to a new space as an integrated or blended space with its own emergent structure.

5 The national anthem is performed in a grand style, which is simply suggested by metonymical mappings throughout the rest of the video as the music follows the rhythm and style of a military march accompanied by percussions (military drums). This particular style was typical of the former Yugoslav (now
} 
greement with the lyrics of the song in which the author uses a low style language to deal with everyday life of gangsta groups. The layering (of these mutually exclusive elements) in a multimodal text thus produces new concepts. The parody in the video occasionally turns into the caricature of state leaders and ceremonial features (also resulting in the parody of identity markers of the collective as an ethnos) and into the mockery of the icons of popular culture, especially of pop music. The function of the parade is identified with entertainment, and consequently they both assume the function of a spectacle. On the one hand, the video displays flags, soldiers, vehicles, weapons, and majorettes as symbols of the (military) state and spectacle. On the other hand, the verbal code stands for the narco-society with drug addicts, social outcasts and an array of small criminals who are representatives of the parastate and also observers of the spectacle. The music incorporates both: the high and the low style. Portraying state leaders as participants in a frivolous spectacle becomes an act of provocation and mockery of the state. The pictorial mode and the sound effects transmit the image of the state as an emblematic affair possessing the quality of show business and entertainment: the official protocol directly incorporates elements and strategies of entertainment such as music, performers, stage and staging. The reality of the national community is contained in the verbal message marked by slang terminology and profanities. The video displays representatives of the state and the entertainment industry, the official protocol and machinery as symbols of dehumanization, and this is contrasted with the content of the verbal message: the lives of small criminals, addicts and other people living on the social margin. The verbal message containing vulgar slang and references to corporeality, hypersexuality and bestial behavior is actually representative of the human reality which casts new light on the relationship between the high and the low. The result is the reversal of the social norm: the state receives a negative connotation, and the criminal society receives a positive connotation.

The image and the verbal text are sometimes directly connected on the denotative level: a particular lexeme in the text of the song is juxtaposed with a frame showing an object or a scene which is in a way related to the lexeme. The juxtaposition is usually antonymic and results in both a comic effect and criticism: the collocation kožne sandale ("leather sandals") is followed by the image of military boots stomping, the lexeme kožnjaci ("leather jackets") is illustrated by the image of historical military units, the phrase pogled pedofila ("the look of a pedophile") is linked to the boat decorated with rainbow-colored balloons. The attention is dispersed among the visual, the auditory and the verbal content, which is incompatible with each other, and the focus is on establishing new meanings at the site of the deconstructed generic space. This process of meaning deconstruction and reconstruction produces parody. The parallelism between the represented image and

Slovenian) avant-garde pop/rock group Laibach, whose militaristic mode of expression set the standards of musical political provocation during the communist era (e.g. by using Nazi symbols as reference), but whose artistic image was also strongly inscribed into the domain of the spectacle and imagination, and predominantly marked by overt staging. Their work promotes the model of Gesamtkunstwerk that implies an interaction of various communication modules, as a synthesis of different forms of artistic expression musical, textual, costumographic and choreographic (cf. Stojanac 2014). 
the reality of the verbal message is explicated by the spatial and temporal localization contained in the verse: 2012-e cila Hrvatska je krek kuća ("In 2012 the whole of Croatia is a crack house"). This metaphoric phrase conceptualizes the state (as an abstract social community) in terms of a concrete space (a house in which drug addicts reside). Social deviation is conceptualized as an illness/addiction of the metaphorical social body which is grounded in the conceptual metaphor of the body politic (cf. Musolff 2010). There is a similar metaphor in the 2010 film The Fighter by David O. Russell: in the documentarywithin-the-film dealing with smoking crack in the USA we find out that in Lowell, Massachusetts, a crack house is called the white house due to the color of its facade; in the metaphor the mapping is reversed and goes from the concrete "low" space to the concrete "high" space, the latter being a metonymic and abstract symbol of power.

The color of the facade in the film has the same function as the multimodal juxtaposition of the image, the sound effects and the verbal text that stand in mutual contrast in the video "Konan". The metaphoricity of this juxtaposition is particularly evident in a scene from the video. The scene showing arms/hands carrying flags (a flag as an explicit symbol of the state used in the context of a military parade becomes a sign of the state's power and a symbol of a uniformed dehumanized collective) appears simultaneously with the following verse: Zasučemo rukave, važemo kile ne važemo grame ("We roll up our sleeves, we weigh in kilos, and not in grams") which conceptually also conveys the idea of busy hands - but hands busy with weighing drugs. By juxtaposing the image (motionless hands/ arms carrying flags) and the text (the Croatian idiomatic phrase zasukati rukave "to roll up one's sleeves" means "to start working hard on something"), the action is metaphorized as embodied manipulation (an action using one's hands) creating a contrast between the hands of the collective machine and the hands of a resourceful individual. The concepts of "builders" hands and "bread winners" hands thus carry the meaning across the domains: the represented and the real, the dehumanized and the human.

Figure 2 shows the multimodal schema of the described parodic integration.



\subsection{THE CITY AS A CAGE}

The city is observed through a parodic discrepancy between exterior and interior spaces, which is coded in the verbal message as well as in the visual presentation. The (en)closed spaces of a zoo and a cage replace the idea of an open city, as a free space and community. In this example, the parodic integration is implied in the representation of the human as animalistic; bestial properties are identified with the human and placed on the higher level of hierarchy than the controlled human beings.

The fact that the city is represented by a cage is relevant for conceptualizing the community as residing inside a bounded and limited habitat and therefore possessing the quality of a pack. ${ }^{6}$ The parallelism between a human community and an animal pack is further strengthened by an act of labelling of body parts, where sexuality is a reflection of the biological hierarchy? The concept of power manifested as a bodily presence, instead of being a sign of the degradation of reason, is in line with the evolutionary concept of an embodied mind. ${ }^{8}$

The verbal and visual metaphor HUMANS ARE ANIMALS is manifested in the sequence which shows placing the label "Split zoo" onto body parts and thus branding them. The label "Split zoo" is at the same time a sign of belonging to a community and a reminder of biological hierarchy. The whole sequence with its metaphorical human-animal reference emphasizes the postmodern concept of theatralization of the body and spectacularization of reality. Reference to reality is replaced by a reference to the simulacrum of the media world: by the act of labelling, hands are directly involved in the production of the spectacle. Buttocks are shown in the act of twerking, which is a content highly exploited in the media, ${ }^{9}$ and breasts, as a classical symbol of sexualized femininity, belonging to Gabrijela Periš, Miss Adriatic Croatia, whose appearance in many other videos by the same artist, usually with a very provocative cleavage, has evolved into a kind of artistic trademark..$^{10}$ The whole scene demonstrates that the reality of the world from the bottom of the society, being an alternative to a dehumanized collective, is also in many ways determined by the spectacle which has become an inevitable form of existence, even when resulting from critical distancing.

Dragaš (2018) points out that Krešo Bengalka's album Split ZOO “deletes the boundaries between the human community of a wild city and its zoo". The fact that it has been shut down makes the Split zoo part of a rather long series of abandoned economic, cultural

\footnotetext{
${ }^{6}$ A pack is characterized by movement limited inside its own territory (Paić 2018: 17).

7 "Therefore, power does not arise from the idea that an animal has about the "self". The source thereof resides inside the bodily structure. It is the bodily structure that decides on physical strength, giving the alfa male not only "the natural right" to mate with an (un)limited number of females, but also taking on the huge responsibility to discipline the monkey community on the conquered territory. Sexual division of power corresponds to domination within the animal social pyramid" (Paić 2018: 17).

${ }^{8}$ Lakoff and Johnson's notion of Darwinism of reason refers to the characteristic of human reason that even in its most abstract form it does not transcend, but rather makes use of our animal nature (1999: 4).

${ }^{9}$ The artist's public performance with twerker Sara Siefert has received significant media attention. Sara Siefert became known after her appearance in the Supertalent show (the video clip of her twerking act has more than 15 million views on Youtube). Cf. Barić 2018.

${ }^{10}$ Auditioning for the video went like this: "Simply, I just came to the agency looking for two women for the video, and Gabrijela was twice as good as the others" (Bukna 2018).
} 
and sporting activities, some of which have partaken in the city's public life for a long time. Existing no longer on the level of concrete content, they continue to survive on the representational level of the city's collective memory. "Deleting the boundaries" between the two biological communities takes the form of a metaphorical mapping which is universally based on the conceptual metaphor HUMANS ARE ANIMALS. The author himself says that the album is "about me and other animals" (Škoro 2017). Bestiality is not found in particular bestial (monstrous) features, but resides in the eye of the observer whose frivolous look becomes the vantage point. The author himself admits that the concept of the album is inspired by the film Planet of the apes: the civilization is controlled by monkeys, and people are locked inside cages, as beings from the lower levels of the hierarchical structure. ${ }^{11}$ The caged people are viewed from the outside as specimens, attractions or deviations, and the look back from the cage is not only a reflection of the bestiality observed, ${ }^{12}$ but is also the reflection of the knowledge that comes from below and is opposed to the sustained hierarchy of power. ${ }^{13}$ The displaced zoo is swallowed by the city that is being emptied of its content (life from below) and recreated as a tourist postcard (a representational image from above); ${ }^{14}$ the author himself explains: "In summer, when I see middle-aged Koreans in lines taking photos of windows and balconies of 'natives' of the Split ghetto, I understand where the zoo is and where the city is" (Jerković 2017). The cover of the album Split ZOO showing the face of a man with eyes wide-open is also constructed on a verbal and visual metaphor: the man appears behind an obstacle, which resembles two black vertical bars and one white crooked bar, but is actually the stylization of the letters ZOO. The image suggests a kind of confinement, but this confinement can be understood in both ways. The person being observed in the cage is at the same time the person observing. This fact disturbs the relationship between the inside and the outside. ${ }^{15}$

\footnotetext{
${ }^{11}$ According to the cultural model of the GREAT CHAIN OF BEING, as given by Lakoff and Turner (1989), higher-level beings of the hierarchy possess some properties that are specific for their species but they also possess all the properties of lower-level beings, i.e. humans who are at the top level of the hierarchy, and possess the properties of physical things, complex objects, plants and animals. By reversing the position of humans and animals on the vertical scale of the hierarchy, humans, and not animals, become defined by instinct as their specific property.

${ }^{12}$ Open eyes suggest the use of the stimulants (brate opusti se zjene raširi / šalice palice dim kofeini "relax, dude, pupils dilate / cups and clubs smoke and caffeines", Amfetamini, Split ZOO, Croatia Records, 2018) but at the same time they embody the performer's commercial strategy: in his videos and the photos that he posts on the social networks he regularly has wide open eyes, which has triggered numerous comments and questions why he does not blink and when he will blink; the performer responded by a commercial message: "watch my videos and see if I blink" (Gaščic 2018). We gratefully acknowledge Ivan Marić for this observation. The bestial look is also linked to the concept of the shame of the observed person (cf. the discussion on the naked Derrida exposed to the cat's look in Paić 2018: 304).

${ }^{13}$ The cultural model of SEEING and the conceptual metaphor KNOWING IS SEEING embody the interdependence of knowledge and visual perception; what we know is highly dependent on what we see (and is given as the abstract mind, consciousness and language), cf. Lakoff and Johnson (1999) and Stanojević (2013).

${ }^{14}$ The promoted openness of the city is a neoliberal construct that covers up the enclosure and exclusion of the "wild" local presence in order to create a controlled tourist environment that has been fossilized and displayed for economic consumption as an idyllic postcard, emptied of real life, cf. Čupković 2012.

15 "The monstrous excess of the open look" (Paić 2018: 304) denotes the interconnection between knowledge and the senses, and between existence and being, and is the bases for the production and identification of the Other. In line with this idea, Paić poses a phenomenological question: "Who is actually looking at the other? The other or 'l'?" (Paić 2018: 305).
} 
In the video Uvij, zakolji ("Roll up, smoke out"), scenes taking place inside enclosed spaces, which are separated by clear cuts between shots/sequences, reveal the container metaphor. The interior of a club (which is an environment indicating subcultural affiliation) and a greenhouse (the place where life is grown in controlled conditions, and in this case the place for growing hallucinogenic substances and opiates) are contrasted to exterior city landmarks, such as a petrol station and the Split 3 city block and its recognizable urban layout.16 These locations alternate, repeating one after another, but there is no dynamics between them that would reveal a transversal motion (a passage from one location to another) and consequently in their essence they are static. The delimitation of these spaces by the boundaries of the sequences becomes the mark of their isolation and enclosedness. The exterior shots remain enclosed inside their frame so that the interior maps onto the exterior. The shape of the Split 3 buildings is reminiscent of a closed corridor. The idea of enclosedness is visually suggested by a parallelism between a line of cars at the petrol station (in the background) and by a car in front of the station that dominates the foreground of the frame and simultaneously functions as a status symbol and typical iconography of the gangsta genre. The parody of the openness concept (both verbal and visual) is not generated by contrasting the verbal and the visual; it is rather semantic transfer that triggers the contrast between the cognitive expectation and the real perception of an "open" space. A series of smaller public spaces, which are presented as mutually disconnected and confining all movement within their own boundaries, function here as static and territorially bound containers of identity.

Figure 3 represents the above-mentioned integration.
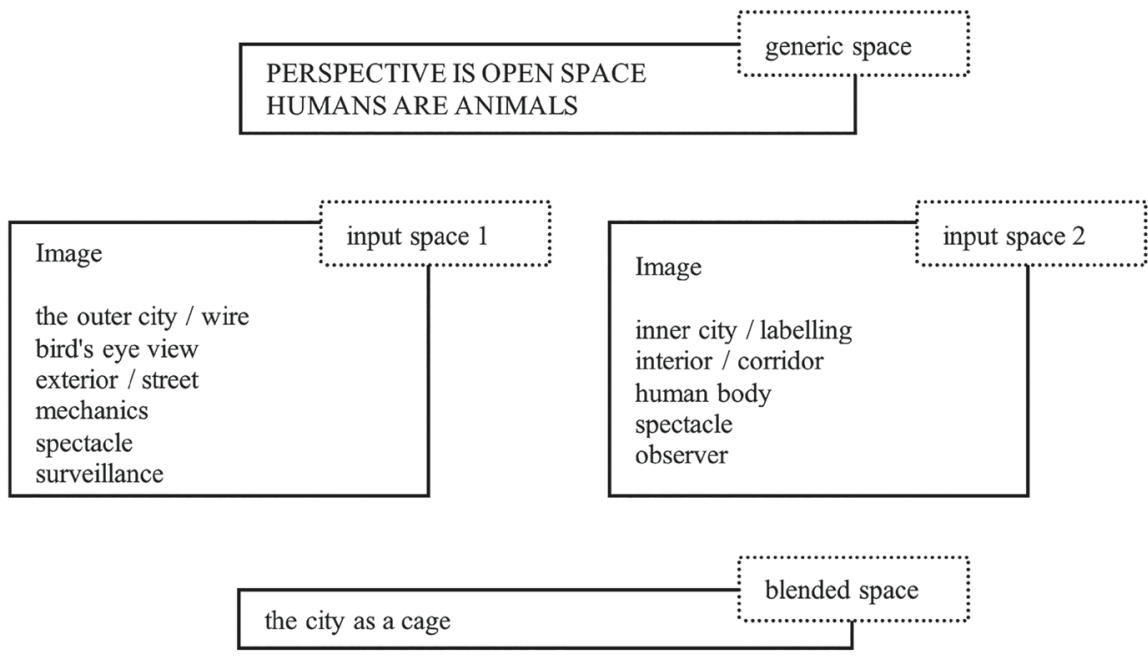

\footnotetext{
${ }^{16}$ The Split 3 block of buildings is one of the most famous projects of urban planning in socialist Yugoslavia. At the time when the video was made, the architecture of Split 3 was being shown in the The Museum of Modern Art (MoMA) in New York as part of the exhibition "Toward a Concrete Utopia: Architecture in Yugoslavia, 1948-1982". The exhibition generated an extreme interest of the media highlighting the quality of "a concrete utopia" that was based on the synergy achieved between the blocks of residential buildings and the flow of the urban life itself (life, work and leisure), cf. D. D. 2018.
} 


\section{A TRAPPED INDIVIDUAL AS A TECHNOLOGICAL BEING}

Boundary, enclosedness and the container schema are significant in understanding how individual human beings are presented in the studied videos. The enclosed quality of the exterior and interior spaces is used to conceptualize the containment of time ${ }^{17}$ and this is achieved by means of subjective experiencing of hopelessness, hollow existence, and boredom. The conceptual metaphor TIME IS MOTION THROUGH SPACE is replaced by the concept of time as an immobility container. This reversal produces the parodic distancing from the common conception of time.

The title of the video and trap song Ovdi ("Here") is an adverb of place whose linguistic form is suggestive of the region (ovdi is a regional variety of the standard adverb ovdje) and also implies the point in time (now). Being an abstract category, time is conceptualized by means of meaning transfer from the more concrete categories such as space. TIME IS SPACE is one of the primary conceptual metaphors through which time is conceptualized as a concrete spatial dimension. This metaphor is then expanded into the metaphor TIME IS MOTION THROUGH SPACE that makes the conceptual basis for perceiving movement in real space as the time frame in which the movement is completed. Many languages share common metaphorical phrases, such as doći na svijet (lit. to come to this world) 'to be born', otići (lit. to depart) 'to die', stići na kraj puta (lit. to come to the end of the road), etc., that are all based on the conceptual metaphor LIFE IS A JOURNEY (Lakoff and Johnson 1999): the abstract idea of life, which is also an abstract category of time, is conceptualized as a concrete spatial category - a journey (as motion through space). These conceptual metaphors are also linked to the conceptual schema SOURCE-GOAL-PATH (e.g. phrases such as imati cilj u životu "to have a goal in life", biti bez cilja "to have no goal") that conveys the idea of dynamism and thus stands in contrast to the static conceptual CONTAINER schema (to be located in a closed area, for example in the phrases such as $u$ mislima "in one's thoughts", biti u problemu "to be in trouble", where the abstract mind and emotion are conceptualized as spatial containers). In the video Ovdi, the individual is placed inside an outside space that is bound by wire. Furthermore, he is located in the very center of the confined space - lying down on his back inside the circle, in line with the CONTAINER image schema. The whole community is presented as static and fixed, including different generations of male individuals, from children to grown-ups and elderly men. The crosssection of generations evokes the flow of time which is simultaneously annihilated by spatial containment. The lack of motion in space maps onto the lack of motion in time, which is perceived as the lack of change. Thus, the static aspect prevails and is driven by idleness and spectacle (a bottle is shown as a constituent part of the shared identity; it also does the marketing for an alcoholic beverage of the brand that sponsored the video and whose name is revealed in the final frame).

\footnotetext{
17 The concept of time is replaced by the concepts of uniformity, permanence and "enclosed temporality" (Paić 2018: 17). Paić (2018) discusses the scene from Stanley Kubrick's 2001: A Space Odyssey as an example of the living condition of the pack of anthropoid apes who are gnawing bones out of boredom.
} 
In the video Otpor "Resistance" the container image schema provides the link between the representations of interior spaces: the idea of confinement and hopelessness is connected to the idea of centrality and perpetuity of circular motion that is in itself contrary to the notion of escape. There are two (or three or four) main locations "rotating" in the video. One location is the interior of an apartment inhabited by the performer and his multiple clones. The multiplicity of the performer is indicative of his artificial origin. The rooms and the corridor as living spaces are observed from one central point of view occupied by an unstable but otherwise stationary camera. The only motion exhibited is achieved by zooming and rotating the camera slightly to the left or right, thus producing the idea of circularity of what is otherwise a linear environment. The idea of circular entrapment is also visualized by the second space - a circle demarcated by a beam of spotlight inside an otherwise undefined area shrouded in darkness and inhabited by a female embodiment of a chained winged creature. Similar darkness characterizes the third space inhabited by the performer in a "physical" form. Though these "undefined" spaces enclosed in darkness are separated by editing cuts, similar lightning conditions suggest the possibility of coexistence in the same physical environment. A circle of light created around the chained winged creature, embodied by the previously mentioned Miss Adriatic, is at the same time reminiscent of a prison and the stage. This isolated theatrical body rounds up the whole idea of the spectacle and exists alongside but separate from the multiplied performer, functioning as the matrix, thus extending explicitly into the world of a virtual surrogate cage, that is at the same time the materialized mind. Imprisonment inside the circle of idleness, theatralization and simulacrum is also manifested verbally: samo trčiš isti krug ("you are running the same circle"). The repeating verbal expressions such as nemaš di, nemaš šta; čemu otpor, nemaš di; čemu otpor, nemaš šta "you've got nowhere to go, nothing to do, why resist, you've got nowhere to go; why resist, you've got nothing to do" create a link between the visually created idea of no physical place of exit (circularity as perpetual motion lacking any intentional movement towards a concrete goal) and the idea of idleness and lack of any production industry (the arms dressed in rolled-up sleeves of carefully ironed shirts have no other occupation but indulging in acts of hedonism, such as smoking Cuban cigars and drinking alcohol). ${ }^{18}$

The juxtaposition of the chained (female) person - whose appearance and body evoke the bestiality from the previous videos and whose clothing (wings) refer to the production of a surrogate space of superreality, and the (artificial) matrix as an embodied "superconsciousness" - creates the metaphor of man-animal-machine of the technosphere (Paić 2018), where the differences between a man and an animal become irrelevant. Instead, a third, artificial entity is conceptualized as the camera-eye, the only entity that is in any kind of motion (a hesitant, slightly swaying hand-held camera). The inanimate and immobile machine becomes alive through movement and turns into an active observer

\footnotetext{
${ }^{18}$ Discussing the relationship between language and work, Paić points out that life becomes "the zone in which 'merchandise' and 'thing' are no longer distinguished" and "the construction of that which is called a dehumanized 'being"' (2018: 33).
} 
- an eye that looks inside, and whose sharp mechanical manner of shifting its attention, embodied by "nervous" sudden zooming, reveals the curiosity of an artificial (perhaps still underdeveloped) consciousness. ${ }^{19}$ The creation of a technological being is demonstrated by the final outcome of the parodic play with conventions, primarily by juxtaposing and integrating the exterior and the interior, the static and the dynamic, as well as by erasing the distinction between "the high" and "the low".

Figure 4 shows the integration represented by the above-mentioned video.
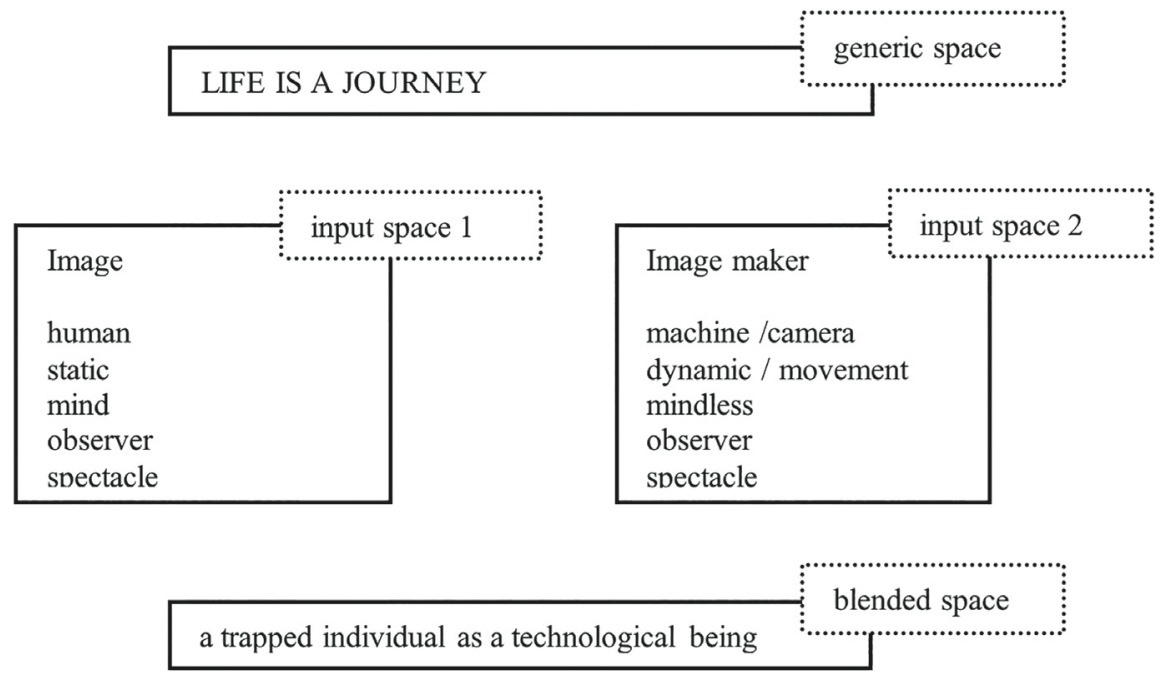

\section{CONCLUSION}

The case studies point to cognitive grounding of parody and provide evidence that parody does not only employ strategies of metaphorical and metonymical mappings but is often underlined by more elaborate conceptual integration structures. In gansta rap music videos, parody surfaces as a multimodal blend providing a complex network of (hints of) signification.

Multimodal metaphors, such as the state as a crack house, the city as a cage and a trapped individual as a technological being, in which the models of representation of human communities and individuals are disintegrated, are used to demonstrate the specificities of parodic integration and point to its grounding in conceptual metaphors: the body politic (NATIONS ARE BODIES), PERSPECTIVE IS OPEN SPACE, HUMANS ARE ANIMALS, and LIFE IS A JOURNEY/MOVEMENT. The distortion of conceptual metaphors

${ }^{19}$ Camera-eye is a concept attributed to Vertov (1984) but Vuillermoz (1927: 40) expands the idea of film vision and links the "cyclopean eye" of the camera to its "mechanical brain" (translated by S.D.). 
from the generic space is achieved by setting up disanalogies between real and virtual input spaces. Metaphorical contrasts and reversals of conventional metaphors whose function is to address social criticism are conceptually grounded and demonstrate universal properties that clearly transcend the context of the media and the genre.

\section{REFERENCES AND SOURCES}

Barić, Vid. 2018. “Tvrd, tvrđi, najtvrđi. Krešo Bengalka u ožujku predstavlja jedan od iščekivanijih regionalnih rap albuma - Split ZOO”. 100 posto, 22 February. Available at: https://100posto.jutarnji.hr/ scena/kreso-bengalka-u-ozujku-predstavlja-jedan-od-iscekivanijih-regionalnih-rap-albuma-splitzoo.html (accessed 27 February 2019).

Bukina, Ivana. 2018. "Krešo Bengalka. 'Ljudska potreba za pripadanjem nečemu je postala mana, a ne vrlina”'. T portal. Available at: https://www.tportal.hr/showtime/clanak/kreso-bengalka-ljudskapotreba-za-pripadanjem-necemu-je-postala-mana-a-ne-vrlina-foto-20180501 (accessed 19 February 2019).

Caldwell, David L. 2008. "Affiliating With Rap Music. Political Rap or Gangsta Rap?". Novitas-ROYAL 2/1: 13-27. Available at: http://www.acarindex.com/dosyalar/makale/acarindex-1423909879.pdf (accessed 19 February 2019).

Čupković, Gordana. 2012. "Lokalni veliki potencijali u kritičkoj interpretacij”". Narodna umjetnost 49/2: 53-70.

D. D. 2018. "Split 3 kao 'betonska utopija'. Prizori Splita u najpoznatijem muzeju moderne umjetnosti na svijetu". Dalmacija danas, 27 August. Available at: https://www.dalmacijadanas.hr/split-3-kao-betonska-utopija-prizori-splita-u-najpoznatijem-muzeju-moderne-umjetnosti-na-svijetu/ (accessed 28 February 2019).

Dragaš, Aleksandar. 2018. "Splitski gangsta "protiv' zagrebačkog trapa”. Jutarnji list. Available at: https:// www.jutarnji.hr/kultura/glazba/splitski-gangsta-protiv-zagrebackog-trapa-recentni-albumi-kukuai-krese-bengalke-reflektiraju-razlike-izmedu-hrvatskog-sjevera-i-juga-7086324 (accessed 19 February 2019).

Fauconnier, Gilles and Mark Turner. 1998. "Conceptual Integration Networks". Cognitive Science 22/2: 133-187. https://doi.org/10.1207/s15516709cog2202_1

Forceville, Charles. 2016. "Pictorial and Multimodal Metaphor". Handbuch Sprache im multimodalen Kontext. N. M. Klug and H. Stöckl, eds. Berlin: Mouton de Gruyter. Available at: https://www.researchgate.net/publication/281711889_Pictorial_and_multimodal_metaphor_2016 (accessed 15 December 2018). https://doi.org/10.1515/9783110296099-011

Gaščić, Denis. 2018. “Pogledajte moje spotove i provjerite jesam li trepnuo". 24 sata, 1 April. Available at: https://www.24sata.hr/show/pogledajte-moje-spotove-i-provjerite-jesam-li-trepnuo-567008 (accessed 2 March 2019).

Jerković, Darko. 2017. "Krešo Bengalka. Nova izdanja beskompromisnog splitskog repera". Glas Slavonije. Available at: http://glas.hr/346201/11/Udjem-u-kvartovski-kafic-i-u-nekoliko-sekundinamirisem-sve-probleme-drzave-i-drustva (accessed 19 February 2019).

Korkut, Nil. 2005. Kinds of Parody from the Mediaeval to the Postmodern. Ankara: Middle East Technical University [Ph.D. Thesis]. Available at: www.etd.lib.metu.edu.tr (accessed 28 February 2019).

Lakoff, George and Mark Turner. 1989. More than Cool Reason. A Field Guide to Poetic Metaphor. Chicago, London: The University of Chicago Press. https://doi.org/10.7208/chicago/9780226470986.001.0001

Lakoff, George and Mark Johnson. 1999. Philosophy in the Flesh. New York: Basic Books.

Langacker, Ronald W. 1987. Foundations of Cognitive Grammar. Stanford: Stanford University Press. 
Musolff, Andreas. 2010. "Perspectives in Politics and Discourse". Discourse Approaches to Politics, Society and Culture, Band 36: 23-41. https://doi.org/10.1075/dapsac.36.05mus

Paić, Žarko. 2018. Tehnosfera, 1. Žrtvovanje i dosada. Životinja-Čovjek-Stroj. Zagreb: Sandorf \& Mizantrop. Stanojević, Mateusz M. 2013. Konceptualna metafora. Zagreb: Srednja Europa.

Stojanac, Vjeran. 2014. "Što je Laibach, odnosno Laibach Kunst?". Pokret/movement 5: 2-7. Available at: https://dokumen.tips/documents/sto-je-laibach-odnosno-laibach-kunst.html (accessed 28 February 2019).

Škoro, Tajana. 2017. Krešo Bengalka. Split Zoo obuhvaća mene i druge ‘životinjske jedinke’ grada Splita. MIXETA.NET Available at: https://mixeta.net/2017/12/20/kreso-bengalka-split-zoo-intervju/ (accessed 14 April 2018).

Vertov, Dziga. 1984. "The Council of Three". Kino-Eye. The Writings of Dziga Vertov. Annette Michelson, ed. Berkley etc.: University of California Press, 14-21.

Vuillermoz, Émile. 1927. “La musique des images”. L’Art cinématographique 3: 39-66.

\section{Media sources}

Konan. 2013. Kiša metaka. Video by Kiša metaka (and HRT). Available at: https://www.youtube.com/ watch?v=NBHas6RolyE (accessed 15 February 2019).

Otpor. 2019. Krešo Bengalka. Video by Pilot studio. Available at: https://www.youtube.com/watch?v= A1RQ h2flZHs (accessed 15 February 2019).

Ovdi. 2018. Krešo Bengalka. Video by Rino Barbir. Available at: https://www.youtube.com/watch?v$=$ NgJcFT8oUKU (accessed 15 February 2019).

Uvij, zakolji. 2018. Krešo Bengalka feat. Vuk Oreb and Žuvi. Video by Marin Jurčević. Available at: https:// www.youtube.com/watch?v=OFjOdAtif7M (accessed 15 February 2019).

Split Zoo. 2018. Album cover: Marijan Jurčević. Croatia Records.

\section{VIŠEOSJETILNA METAFORA U FUNKCIJI PARODIJSKE INTEGRACIJE U GLAZBENIM SPOTOVIMA HIP-HOP IZVOĐAČA}

Interpretiraju se izdvojeni primjeri višeosjetilnih metafora u spotovima i naslovnicama albuma kojima su predstavljeni rap uradci Kreše Kulašina, poznatog pod umjetničkim imenom Krešo Bengalka, te skupine Kiša metaka. Proučavanim se višeosjetilnim metaforama društveni kriticizam ukalupljuje u spektakl kao tipično obilježje gangsta žanra. Analizom izdvojenih primjera upućuje se na konceptualnu integraciju kao jedan od važnih mehanizama proizvodnje parodijskoga odmaka koji je vidljiv $u$ izobličenju konvencionalnih prikaza eksterijera i interijera, statičnosti i dinamičnosti, kao i u kontrastiranju osjetilnih senzacija (auditivnih, vizualnih i verbalnih).

Ključne riječi: kognitivna semantika, konceptualna metafora, višeosjetilna metafora, spektakl, parodija, gangsta rap 